Homepage: https://ojs.stiem-bongaya.ac.id/index.php/BJRA

\title{
Pengaruh Audit Kinerja dan Pengendalian Intern Terhadap Kinerja Perusahaan Daerah Air Minum (PDAM) Kota Gorontalo Dengan Good Corporate Governance Sebagai Variabel Intervening
}

\author{
Arifin $^{1)}$ \\ ${ }^{1}$ Fakultas Ekonomi, Universitas Ichsan Gorontalo \\ email: arifin.unisan@gmail.com
}

(Diterima: 02-Februari-2018; di revisi: 27-Februari-2018; dipublikasikan: 18-April-2018)

\begin{abstract}
:
This research aim to to know how relation make an audit of performance with Control of intern; how influence make an audit of internal control and performance either through parsial and also by simultan to governance corporate good; and how influence make an audit of performance, internal control and of good governance corporate either through parsial and also by simultan to performance of PDAM Town of Gorontalo.

Sampel selected pursuant to sampling purposive counted 20 responder people at middle management level of to to the. Data collecting methode the used is observation, and interview of kuesioner. Data analysed with model estimate equation of simultan.

Result of research indicate that there are positive relation and signifikan make an audit of performance with internal control, there are positive influence and signifikan make an audit of internal control and performance either through parsial and also by simultan to good governance corporate, there are positive influence and do not signifikan make an audit of performance to performance of PDAM Town of Gorontalo and internal control have an effect on and negativity of signifkan to PDAM Town of Gorontalo, but good governance corporate have an effect on positive to performance of PDAM Town of Gorontalo.
\end{abstract}

Keywords: Accounting Information System; Performance

\section{PENDAHULUAN}

Tekanan terhadap sektor publik khususnya organisasi pemerintah baik pusat maupun daerah serta badan usaha milik daerah (BUMD) maupun badan usaha milik negara (BUMN) untuk memperbaiki kinerjanya mendorong dibangunnya sistem manajemen organisasi sektor publik yang berbasis kinerja (performance-based management), hal ini dikarenakan bahwa sektor publik sering dinilai sebagai sarang inefisiensi, pemborosan, sumber kebocoran dana, dan institusi yang selalu merugi. (Mardiasmo, 2004:4). Organisasi sektor publik pemerintah merupakan lembaga yang menjalankan roda pemerintahan yang sumber legitimasinya berasal dari masyarakat. Oleh karena itu, kepercayaan yang diberikan oleh 
masyarakat kepada penyelenggara pemerintahan haruslah diimbangi dengan adanya pemerintahan yang bersih. Perusahaan Daerah Air Minum (PDAM) Kota Gorontalo merupakan salah satu asset pemerintah daerah Kota Gorontalo, dimana organisasi ini memberikan pelayanan publik khususnya kepada masyarakat Kota Gorontalo dan sekitarnya dalam penyediaan kebutuhan air minum bersih. Oleh karena itu, Perusahaan Daerah Air Minum (PDAM) Kota Gorontalo dalam memberikan pelayanan sangat membutuhkan tata kelola organisasi/perusahaan yang baik (good corporate governance). Agar good corporate governance dapat berjalan dengan baik, maka salah satu hal yang diterapkan PDAM Kota Gorontalo adalah audit kinerja dan pengendalian intern.

Audit kinerja adalah suatu proses yang sistematis untuk memperoleh dan mengevaluasi bukti secara objektif atas kinerja suatu organisasi, program, fungsi atau aktivitas. Pengendalian intern menurut Ikatan Akuntan Indonesia (2001:319.2) adalah suatu proses yang dijalankan oleh dewan komisaris, manajemen dan personel lain entitas yang didesain untuk memberikan keyakinan memadai tentang pencapaian tiga golongan tujuan yaitu keandalan pelaporan keuangan, efektivitas dan efisiensi operasi dan kepatuhan terhadap hukum dan peraturan yang berlaku, yang terdiri dari 5 (lima) komponen yaitu: lingkungan pengendalian, penafsiran resiko, sistem informasi dan komunikasi akuntansi, aktivitas pengendalian dan pemantauan.

Sementara corporate governance, menurut Cadbury Committe of the United Kingdom (1999), mengemukakan bahwa seperangkat peraturan yang mengatur hubungan antara pemegang saham, pengurus (pengelola) perusahaan, pihak kreditur, pemerintah, karyawan serta para pemegang kepentingan intern dan ekstern lainnya yang berkaitan dengan hak-hak dan kewajiban mereka, atau dengan kata lain suatu sistem yang mengatur dan mengendalikan perusahaan. Pada good corporate governance, Perusahaan Daerah Air Minum (PDAM) Kota Gorontalo sebaiknya meninggalkan paradigma lama, di mana Perusahaan Daerah Air Minum (PDAM) Kota Gorontalo dulu sebagai cost center, kini harus merubah orientasinya dengan memadukan service public oriented dan profit oriented dengan mengedepankan terciptanya suatu lembaga publik yang berorientasi pada value for money

Penelitian ini terkait dengan pengendalian intern dan penerapan prinsipprinsip good corporate governance (GCG) yang dilakukan Prasetyono dan Kompyurini (2007:17). Berdasarkan hasil penelitian ditemukan bahwa pengendalian intern memiliki pengaruh positif terhadap penerapan prinsipprinsip good corporate governance pada tingkat yang cukup. Kondisi ini memperlihatkan bahwa semakin baik pengendalian intern akan mendorong keberhasilan penerapan prinsipprinsip good corporate governance, serta pengendalian intern dan good corporate governance secara simultan berpengaruh terhadap kinerja organisasi.

Kemudian terkait dengan audit manajemen, komitmen manajer, pengendalian intern terhadap penerapan prinsip-prinsip good corporate governance dan kinerja Badan Usaha 
Milik Negar yang dilakukan Pratolo (2007:17), menjelaskan bahwa terdapat hubungan antara aspek sistem dalam hal ini ditunjukkan oleh audit manajemen dan pengendalian intern dengan aspek personil yang ditunjukkan oleh komitmen manajer pada organisasi. Pelaksanaan audit manajemen tanpa disertai komitmen manajer pada organisasi yang tinggi dimungkinkan audit manajemen tidak akan efektif. Pengendalian intern merupakan tanggungjawab manajer, sehingga pengendalian intern tanpa disertai komitmen manajer pada organisasi dimungkinkan tidak akan tercipta pengendalian intern yang efektif. Hal lain yang ditunjukkan oleh temuan tersebut adalah adanya hubungan antar sistem didalam organisasi dalam hal ini adalah audit manajemen dan pengendalian intern. Audit manajemen tanpa disertai pengendalian intern yang efektif memungkinkan audit manajemen tersebut tidak optimal pula. Sebaliknya pengendalian intern yang bertujuan untuk menjaga reliabilitas dan integritas informasi, kepatuhan terhadap kebijakan, rencana, prosedur, hukum dan kebijakan, pengamanan asset, penggunaan sumber daya secara ekonomis dan efisien, pencapaian tujuan dan sasaran yang telah ditetapkan untuk operasi dan program yang tidak disertai dengan pelaksanaan audit manajemen maka pengendalian intern tersebut tidak akan efektif pula. Sementara penelitian yang dilakukan oleh Darmawaty (2004:13) tentang hubungan corporate governance dan kinerja perusahaan, menjelaskan bahwa corporate governance bisa memiliki keterkaitan dengan kinerja operasi perusahaan. Dimana pada corporate governance mampu mempengaruhi kinerja pasar perusahaan tetapi dengan membutuhkan waktu, artinya bahwa terdapat hubungan positif antara indeks corporate governance dengan kinerja perusahaan jangka panjang.

Berdasarkan pemaparan di atas, maka dilakukan penelitian dengan tujuan untuk mengetahui hubungan antara audit kinerja dengan pengendalian intern, mengetahui pengaruh audit kinerja dan pengendalian intern baik secara simultan maupun parsial terhadap good corporate governance serta mengetahui pengaruh audit kinerja, pengendalian intern dan good corporate governance baik secara simultan maupun parsial terhadap Kinerja PDAM Kota Gorontalo.

\section{METODE}

\section{Pendekatan Penelitian}

Penelitian ini termasuk jenis penelitian survey dengan pendekatan kuantitatif yaitu penelitian yang menggunakan sampel dan kuesioner sebagai alat pengumpulan data pokok, yang dilanjutkan dengan uji verifikasi yang bertujuan untuk menguji hipotesis yang telah dirumuskan sebelumnya. Penelitian survey yang dimaksud adalah bersifat menjelaskan hubungan kausal dan pengujian hipotesis. Penelitian survei biasanya dilakukan untuk mengambil suatu generalisasi dari pengamatan yang tidak mendalam, tetapi generalisasi yang dilakukan bisa lebih akurat bila digunakan sampel yang representatif

\section{Definisi Operasional}

Untuk analisis variabel-variabel pada penelitian ini, maka penulis mendefinisikan operasionalisasi variabel sebagai berikut: 
1. Audit Kinerja $\left(\mathrm{X}_{1}\right)$ adalah suatu proses yang sistematis untuk memperoleh dan mengevaluasi bukti secara objektif atas kinerja suatu organisasi, program, fungsi atau aktivitas. Dengan demikian pelaksanaan audit kinerja ini dimaksudkan untuk mengevaluasi bukti secara objektif atas kinerja suatu organisasi, program, fungsi atau aktivitas, yang terdiri dari audit ekonomi dan efisiensi serta audit efektivitas, yang bertujuan untuk mengetahui apakah sumber daya organisasi telah diperoleh dan digunakan secara ekonomis, efisien dan efektif, tidak terjadi pemborosan, kebocoran, salah alokasi, dan salah sasaran, guna mencapai target yang ditetapkan serta kepatuhannya terhadap kebijakan dan peraturan perundangan yang disyaratkan.

2. Pengendalian Intern $\left(X_{2}\right)$, adalah suatu proses yang dipengaruhi oleh aturan direksi, manajemen, personalia lainnya, yang disusun untuk memberi jaminan yang berhubungan dengan pencapaian tujuan, antara lain: Kesesuaian dengan undangundang yang ditetapkan dan aturan dan efektivitas dan efisiensi operasi (kegiatan). Pengendalian Intern dimaksudkan untuk memberikan keyakinan memadai bahwa tujuan pengendalian dapat dipenuhi yang terdiri dari lingkungan pengendalian, penetapan risiko manajemen, sistem informasi dan komunikasi akuntansi, aktivitas pengendalian dan pemantauan.

3. Good Corporate Governance $\left(Y_{l}\right)$ adalah suatu proses dan struktur yang digunakan oleh organisasi untuk meningkatkan keberhasilan usaha dan akuntabilitas perusahaan guna mewujudkan nilai pemegang saham dalam jangka panjang dengan tetap memperhatikan kepentingan berbagai pihak yang berlandaskan peraturan perundangan dan nilai-nilai etika. Good corporate governance ini diukur dengan prinsip-prinsip transparansi, akuntabilitas, tanggung jawab dan keadilan/kewajaran.

4. Kinerja Perusahaan $\left(\mathrm{Y}_{2}\right)$, dimaksudkan untuk kinerja Perusahaan Daerah Air Minum Kota Gorontalo di ukur berdasarkan pendekatan balanced scorecard, yang terdiri dari kinerja non keuangan dan kinerja keuangan. Namun pada penelitian ini kinerja keuangan tidak dimasukkan dalam model disebabkan karena penulis hanya melakukan penelitian pada satu lokasi yaitu Perusahaan Daerah Air Minum Kota Gorontalo.

\section{Populasi dan Sampel}

Populasi yang dipilih dalam penelitian ini adalah pegawai yang bekerja pada Perusahaan Daerah Air Minum (PDAM) Kota Gorontalo dengan jumlah sebanyak 131 Orang. Dari jumlah populasi sebanyak 131 orang, maka penulis melakukan pengambilan sampel dengan menggunakan metode purposive sampling yaitu pemilihan sampel berdasarkan pada karakteristik atau pertimbangan tertentu yang dianggap mempunyai sangkut paut dengan karakteristik yang sudah diketahui sebelumnya. (Umar,1998:82) dan Sugiyono (2007:61). Dengan demikian jumlah keseluruhan sampel sebanyak 20 Orang.

\section{Metode Pengumpulan Data}


Untuk memperoleh data tersebut diperlukan dalam penelitian ini menggunakan data primer yang merupakan data langsung yang diperoleh dari lokasi penelitian digunakan cara metode penelitian lapangan (field research) dengan teknik pengumpulan data adalah kuesioner, wawancara, observasi serta Data sekunder diperoleh dari penelaahan kepustakaan yang berupa dasar-dasar teoritis, hasil penelitian terdahulu dan bahan-bahan yang mendukung yang relevan dengan penelitian ini.

\section{Metode Analisis Data}

Untuk memastikan bagaimana pengaruh Audit kinerja $\left(\mathrm{X}_{1}\right)$, pengendalian intern $\left(\mathrm{X}_{2}\right)$ terhadap Good Corporate Governance $\left(\mathrm{Y}_{1}\right)$ dan Kinerja PDAM ( $\left.\mathrm{Y}_{2}\right)$, maka pengujian dilakukan dengan menggunakan analisis SEM (Structural Equation Modelling) metode alternatif dengan PLS (Partial Least Square). Yamin dan Kurniawan (2009:213), Ghozali (2008:22) mengemukakan bahwa PLS pada dasarnya didefinisikan oleh dua set persamaan, yaitu inner model dan outer model.

\section{HASIL DAN PEMBAHASAN}

Penelitian ini digunakan untuk mengetahui bagaimana pengaruh variabel laten eksogen audit kinerja $\left(\xi_{1}\right)$ dan pengendalian intern $\left(\xi_{2}\right)$ terhadap variabel laten endogen kinerja PDAM Kota Gorontalo ( $\left.\boldsymbol{\eta}_{2}\right)$ melalui variabel good corporate governance $\left(\eta_{1}\right)$. Teknik analisis data yang digunakan adalah analisis SEM-PLS. Dari hasil evaluasi outer model (measurement model) dan model struktural (inner model), maka secara ringkas hasil penelitian dapat dapat digambarkan ke dalam model struktural jalur sebagai berikut:

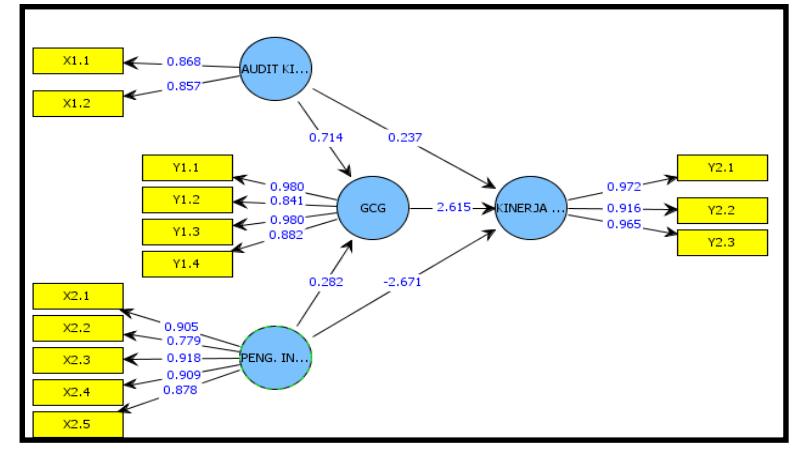

\section{Gambar 1. model simultan Structural}

\section{Equation Model (SEM)}

Dari gambar di atas, maka dapat dibentuk persamaan fungsional dalam model simultan Structural Equation Model (SEM) dengan reduced form sebagai berikut :

Persamaan 1: $\eta_{1}=0,714 \xi_{1}+0,282 \xi_{2}+0,015 \zeta_{1}$ Dengan $\mathbf{R}^{2}=0,985$

Persamaan 2: $\eta_{2}=2,615 \eta_{1}+0,237 \xi_{1}+-$

$2,671 \xi_{2}+0,711 \zeta_{2}$

Dengan $\mathbf{R}^{2}=0,289$

Dari persamaan struktural jalur di atas dapat dijelaskan hubungan antar setiap konstruk. Konstruk audit kinerja $\left(\boldsymbol{\xi}_{1}\right)$ memiliki koefisien pengaruh positif terhadap good corporate governance $\left(\eta_{1}\right)$ sebesar 0,714 artinya semakin baik pelaksanaan audit kinerja, maka pelaksanaan good corporate governance semakin baik pula. Konstruk pengendalian intern $\left(\xi_{2}\right)$ memiliki koefisien pengaruh positif terhadap good corporate governance $\left(\eta_{1}\right)$ sebesar 0,282 artinya semakin baik pengendalian intern, maka pelaksanaan good corporate governance (GCG) juga akan lebih baik. Nilai $\mathrm{R}$ square pada persamaan pertama sebesar 0,985 atau 98,5\% mengindikasi bahwa variasi nilai good corporate governance ditentukan oleh variasi audit kinerja dan pengendalian intern dan 0,015 atau $1,5 \%$ 
ditentukan oleh variasi variabel lain yang tidak dijelaskan dalam model.

Konstruk audit kinerja $\left(\xi_{1}\right)$ memiliki koefisien pengaruh positif terhadap kinerja $\left(\boldsymbol{\eta}_{2}\right)$ sebesar 0,237 artinya semakin baik pelaksanaan audit kinerja, maka kinerja PDAM semakin meningkat. Konstruk pengendalian intern $\left(\xi_{2}\right)$ memiliki koefisien pengaruh negatif terhadap kinerja PDAM $\left(\boldsymbol{\eta}_{2}\right)$ sebesar $-2,671$, artinya bahwa jika pelaksanaan pengendalian intern yang ada sekarang ini di PDAM semakin di pertahankan, maka kinerja PDAM semakin menurun. Kemudian konstruk good corporate governance $\left(\eta_{1}\right)$ memiliki koefisien pengaruh positif terhadap kinerja $\left(\boldsymbol{\eta}_{2}\right)$ sebesar 2,615 artinya semakin baik implementasi good corporate governance, maka kinerja perusahaan semakin lebih baik. Nilai R square pada persamaan kedua sebesar 0,289 atau 28,9\% mengindikasi bahwa variasi nilai kinerja PDAM ditentukan oleh variasi audit kinerja, pengendalian intern dan good corporate governance dan 0,711 atau $71,1 \%$ ditentukan oleh variasi variabel lain yang tidak dijelaskan dalam model.

Hasil pengujian terhadap hipotesis pertama pada penelitian ini adalah audit kinerja memiliki hubungan korelasi positif dengan pengendalian intern sebesar 0,849 atau $84,9 \%$. Hasil ini menunjukkan bahwa dalam pelaksanaan audit tidak dapat dipisahkan dengan pengendalian intern pada sebuah organisasi, semakin baik pengendalian intern maka semakin memudahkan pelaksanaan dalam melakukan kegiatan audit kinerja. Dengan demikian hipotesis yang diajukan pada penelitian ini dapat diterima bahwa terdapat hubungan yang positif dan signifikan audit kinerja dengan pengendalian intern.

Hasil pengujian terhadap hipotesis ke dua pada penelitian ini adalah audit kinerja secara parsial berpengaruh positif dan signifikan terhadap good corporate governance $(G C G)$. pada taraf uji signifikansi 5\% (0.05) sebesar 0,714. Dengan demikian semakin baik pelaksanaan audit kinerja suatu perusahaan maka akan semakin baik pengelolaan organisasi PDAM Kota Gorontalo. Hasil ini sesuai dengan hipotesis bahwa audit kinerja secara parsial berpengaruh positif dan signifikan terhadap good corporate governance. Ini berarti bahwa audit kinerja sangat berperan dalam menciftakan tata kelola organisasi dengan baik, karena dengan adanya audit kinerja akan dapat memberikan rekomendasi kepada pihak manajemen perusahaan untuk perbaikan yang lebih baik.

Hasil pengujian terhadap hipotesis ke tiga pada penelitian ini adalah audit kinerja, pengendalian intern dan good corporate governance baik secara parsial maupun simultan berpengaruh signifikan terhadap kinerja PDAM Kota Gorontalo. Berdasarkan tabel 29, maka dapat diketahui bahwa audit kinerja secara parsial berpengaruh positif namun tidak signifikan terhadap kinerja PDAM Kota Gorontalo pada taraf uji signifikansi 5\% (0.05) sebesar 0,237, ini berati bahwa semakin baik pelaksanaan audit kinerja dalam telaah ekonomi, efisiensi dan efektivitas suatu perusahaan maka akan semakin baik kinerja PDAM Kota Gorontalo. Hasil ini tidak sesuai dengan hipotesis bahwa audit kinerja secara parsial berpengaruh positif dan signifikan terhadap kinerja PDAM Kota Gorontalo. Ini berarti bahwa 
tidak semua pelaksanaan audit kinerja pada suatu perusahaan dapat meningkatkan kinerja organisasi.

\section{KESIMPULAN DAN SARAN}

Dari analisis hasil penelitian dan pembahsan, maka dapat ditarik kesimpulan yaitu

1. Audit kinerja memiliki hubungan positif dengan pengendalian intern sebesar 0,849 $(84,9 \%)$. Besarnya hubungan tersebut menunjukkan bahwa semakin baik pengendalian intern, maka semakin memudahkan pelaksanaan audit sehingga dapat mendorong efisiensi dan efektifitas operasional perusahaan dan ketaatan kepada hukum dan peraturan.

2. Audit kinerja dan pengendalian intern berpengaruh positif dan signifikan terhadap good corporate governance, baik secara parsial maupun secara simultan. Besarnya pengaruh audit kinerja terhadap good corporate governance sebesar 0,714 $(71,4 \%)$; besarnya pengaruh pengendalian intern terhadap good corporate governance sebesar 0,282 (28,2\%); sedangkan besarnya pengaruh audit kinerja dan pengendalian intern secara simultan terhadap good corporate governance sebesar $0,985(98,5 \%)$ artinya good corporate governance dapat dijelaskan oleh model dengan indikasi baik.

3. Audit kinerja, pengendalian intern dan good corporate governance berpengaruh terhadap kinerja perusahaan, baik secara parsial maupun secara simultan. Audit kinerja berpengaruh positif terhadap kinerja perusahaan sebesar 2,104; Pengendalian intern berpengaruh negatif dan signfikan terhadap kinerja perusahaan sebesar -1,934; Good corporate governance berpengaruh positif dan signfikan terhadap kinerja perusahaan sebesar 2,615. Sedangkan audit kinerja, pengendalian intern, dan good corporate governance secara simultan berpeengaruh positif terhadap kinerja perusahaan sebesar $0,259(25,9 \%)$ artinya kinerja perusahaan dapat dijelaskan oleh audit kinerja, pengendalian intern, dan good corporate governance dengan indikasi moderat.

Adapun saran Untuk good corporate governance yang baik bagi PDAM Kota Gorontalo, maka audit kinerja dan pengendalian intern hendaknya disusun secara lebih sempurna dan dilaksanakan secara optimal, efektif dan efisien. Hal ini disebabkan ke dua variabel di atas sangat kuat mempengaruhi baik buruknya good corporate governance pada PDAM Kota Gorontalo. Demikian halnya audit kinerja, pengendalian intern dan good corporate governance dijalankan secara bersama-sama dan dilaksanakan secara sempurna karena ketiga variabel ini sangat mempengaruhi baik buruknya kinerja PDAM Kota Gorontalo baik dari ukuran kinerja keuangan maupun non keuangan.

\section{DAFTAR RUJUKAN}

Atkinson, Anthony A,. 1995. Management Accounting. Second Edition. Prentice Hill. Richard D Irwin, Inc. Pillipines.

Arens, Alvin A \& Loebbecke, James K.. 1997. Auditing, an Integrated Approach. Seventh Edition. 
Upper Saddle River, New Halim, Yersey: Prentice-Hall, Inc.

2000. Auditing Pendekatan

Terpadu, Penerbit Salemba Empat, Simon \& Schuster (Asia) Pte.LTd Prentice-Hall Inc.

Badan Pemeriksa Keuangan Pemerintah. 2004. Pedoman Audit Kinerja Sektor Publik

Badjuri, Achmad \& Trihapsari, Elisa. 2004.
Audit
Kinerja
Pada
Organisasi Sektor Publik
Pemerintah, STIE Semarang

Committee of Sponsoring Organizations of the Treadway Commission. 1992.. Internal Control Integrated Framework (COSO Report).

Darmawati, Deni,. 2004. Hubungan Corporate Governance dan Kinerja Perusahaan, The Indonesia Institute for Corporate Geovernance (ICCG), Simposium Nasional Akuntansi VII Bali, 2005

FCGI (Forum For Corporate Governance In Indonesia). 2002. Tata Kelola Perusahaan (Corporate Governance) The Essence of Good Corporate Governance : Konsep dan Implementasi Perusahaan Publik dan Korporasi Indonesia. Yayasan Pendidikan pasar Modal Indonesia \& Synergy Communication. Jakarta.

General Accounting Office Standards. 1994. Auditing Standards, GAO, Washington DC

Ghozali, Imam. 2008. Structural Equation Modelling Metode Alternatif dengan Partial Least Square, Edisi 2. Badan Penerbit Universitas Diponegoro, Semarang
Abdul. 2003. Sistem Pengendalian Manajemen. Penerbit UPP AMP YKPN Yogyakarta

Haris, Wibisono. 2004. Pengaruh Earnings Management Terhadap Kinerja Di Seputar SEO. Tesis S2. Magister Sains Akuntansi UNDIP. Tidak dipublikasikan

Hartadi, Bambang.1999. Sistem Pengendalian Intern dalam Hubungannya dengan Manajemen dan Audit. Penerbit BPFE Yogyakarta.

Ikatan Akuntan Indonesia - Kompartemen Akuntan Publik, 2001. Standar Profesional Akuntan Publik, Per 1 Januari 2001. Penerbit PT. Salemba, Jakarta

Jensen, Michael C. dan W.H. Meckling. 1976. Theory of The Firm: Managerial Behavior, Agency Cost and Ownership Structure. Journal of Financial Economics 3. hal. 305-360.

Juanim, 2004. Analisis Jalur Dalam Riset Pemasaran, PT. Alfabeta Bandung.

Joreskog, K.G and Wold, H. 1982. Partial Leas Square. In S Kotz \& N. L. Johnson (Eds). Encyclopedia of Statistical Science. Vol 8 (PP. 587-599). New York. Wiley

Kaplan, Robert \& Atkinson, A. 1998. Advanced Management Accounting.. Third ED, Prentice-Hall, New Jersey.

Kaplan, Robert \& Norton. David P.1993. Putting the Balanced Scorecard to Work,. Harvard Business Review. .1996. Translating Strategy Into Action The Balance Scorecard. Harvard Business School. Boston. 
1996, Balanced Scorecard, Penerbit Erlangga Jakarta.

Komariah, Lia. 2007. Internal role of audit as supporter in improving efektivitas internal control supply at pdam tirta pakuan kota bogor. Case study PDAM TIRTA Pakuan Kota bogor

Krismiaji. 2002, Sistem Informasi Akuntansi, Penerbit UPP AMP YKPN Yogyakarta.

Kuncoro, Mudrajad. 2005. Implementasi Manajemen Strategi. Penerbit PT. Salemba Empat Jakarta.

Laporan Audit Kinerja PDAM Kota Gorontalo, 2006. Badan Pengawasan Keuangan dan Pembangunan Perwakilan Provinsi Sulawesi Utara

2007. Badan Pengawasan Keuangan dan Pembangunan Perwakilan Provinsi Sulawesi Utara

2008. Badan Pengawasan Keuangan dan Pembangunan Perwakilan Provinsi Sulawesi Utara

Mahmudi, 2005. Manajemen KInerja Sektor Publik. Penerbit UPP AMP YKPN Yogyakarta

Mardiasmo. 2004. Akuntansi Sektor Publik. Penerbit Andi. Yogyakarta.

2002. "Elaborasi Reformasi Akuntansi Sektor Publik: Telaah Kritis terhadap Upaya Aktualisasi Kebutuhan Sistem Akuntansi Keuangan Pemerintah Daerah". Jurnal Akuntansi dan Auditing Indonesia. FE UII Yogyakarta. Vol. 6 No. 1. Juni. pp. $63-82$.
Messier, William, Jr. 2000. Auditing and Assurance Service- A Systematic Approach. Second Edition. International Edition. Irwin Mc Graw-Hall Co. New York.

Muliyadi, 2001. Sistem Akuntansi. Penerbit

PT. Salemba Empat Jakarta

Nugroho, Fibrianto_Wahyu. 2005. Prosedur Pelaksanaan Audit Kinerja pada BUMN/BUMD di Kantor Perwakilan Badan Pengawasan Keuangan Dan Pembangunan (BPKP) Provinsi Jawa Tengah, Skripsi Universitas Islam Yogyakarta.

Peraturan Pemerintah Republik Indonesia Nomor 60 tahun 2008 Tentang Sistem Pengendalian Intern Pemerintah.

Prasetyono dan Kompyurini, Nurul. 2007. Analisis Kinerja Rumah Sakit Daerah Dengan Pendekatan Balanced Scorecard Berdasarkan Komitmen Organisasi, Pengendalian Intern Dan Penerapan Prinsip-Prinsip Good Corporate Governance (GCG), (Survei Pada Rumah Sakit Daerah di Jawa Timur) Simposium Nasional Akuntansi $X$ Unhas Makassar.

Pratolo, Suryo. 2007. Pengaruh Audit Manajemen, Komitmen Organisasional Manajer, Pengendalian Intern Terhadap Penerapan PrinsipPrinsip Good Corporate Governance Dan Kinerja Badan Usaha Milik Negara Diindonesia, Konferensi Penelitian Akuntansi Keuangan dan Sektor Publik Pertama, Pascasarjana UPNV, Jatim Surabaya, 25-26 April

Richardson, Vernon J. .1998. Information Asymmetry an Earnings Management: Some Evidence. Working Paper, 30 Maret 
Riduwan. 2009. Cara Menggunakan dan Memakai Analisis Jalur (Path Analysis). Penerbit Alfabeta Bandung . 2006. Rumus dan Data dalam Aplikasi Statistika, Penerbit PT. Alfabeta, Bandung . 2004. Metode dan Teknik Menyusun Tesis. Penerbit Alfabeta Bandung

Rika_Sari, Paramita. 2008. Hubungan komite audit terhadap kinerja keuangan melalui good corporate governance sebagai variabel intervening. Tesis Universitas Islam Yogyakarta

Sukrisno, Agoes. 2006. Auditing, Edisi Ketiga. Lembaga Penerbit Fakultas Ekonomi Universitas Indonesia.

Sutisno, 2008. Sitem Pengendalian Intern Pemerintah Bersama Kita Bisa Menyongsong Masa Depan BPKP yang Lebih Cerah, Buletin Paraikatte Perwakilan BPKP Provinsi Sulawesi Selatan, Volume 1 No. 4

Shleifer, Andrei and Vishny, Robert W. 1997. A Survey of Corporate Governance (The Journal of Finance, Vol.52 No.2, Hal.: 737 - 783. June 1997), Penerbit: Oxford: Blackwell Publishing.

Pratisto, Arif. 2004. Cara mudah mengatasi Masalah Statistik dan Perancangan Percobaan dengan SPSS 12. PT. Elex Media Komputindo

Rosita, Devita. 2007. “Pengaruh Mekanisme Corporate Governance Terhadap Manajemen Laba" (Studi Pada Perusahaan Manufaktur Yang Terdaftar Di BEJ Tahun 2005), Skripsi Universitas Brawijaya Malang

Suharto, Harry. 2002. "Compliance Audit Pemerintah Daerah". Media
Akuntansi. Edisi 26. Mei Juni. pp. $14-15$

Sugiyono. 2007. Statistika Untuk Penelitian. Penerbit PT. Alfabeta Bandung.

Tugiman, Hiro. 2000. Pengaruh Peran Auditor Internal Serta Faktor Faktor Pendukungnya Terhadap Peningkatan Pengendalian Internal dan Kinerja Perusahaan. Disertasi Doktor pada Universitas Padjadjaran Bandung.

Ulum, Ihyaul. 2009. Audit Sektor Publik. Penerbit PT. Bumi Aksara, JaKarta.

World Bank. 1998. Policy Research Paper Series No.1894, March 1998, Washington, DC: World Bank

Yadnyana, I Ketut. 2006. Pengaruh kualitas jasa auditor internal terhadap efektivitas pengendalian intern pada Hotel berbintang empat dan lima di Bali. Skripsi Jurusan Akuntansi Fakultas Ekonomi Universitas Udayana

Yamin, Sofyan dan Kurniawan, Heri. 2009. Structural Equation Modelling, dengan Partial Least Square. Penerbit Salemba Imfotek Jakarta.

Yusuf, Amir Abadi. 2007. Auditing, Penerbit PT. Salemba Empat Jakarta

Zarkasyi, Moh. Wahyuddin. Good Corporate Govel pada Badan Usaha factur, Perbankan, aan Jasa Keuangan Lainnya. Penerbit PT. Alfabeta Bandung 